\title{
Correction to: Going for Cold
}

\section{Correction to:}

\section{J. G. Weisend II, G. T. Meaden, Going for Cold, Springer Biographies,}

https://doi.org/10.1007/978-3-030-61199-6

The inadvertently published contents have been corrected as mentioned below.

\section{FM:}

In Page XIII, the content "Courtesy M. Mendelssohn" have been removed.

\section{Chapter 1:}

In Page 1, the numeral 7 has been removed from the first line, as it has been duplicated.

\section{Chapter 2:}

In Page 10, the content ", which was why Simon had given him this as his thesis topic." has been added at the end of the paragraph "The results also cleared up..", below figure 2.2.

\section{Chapter 3:}

In Page 14, the word "very" has been added to $3^{\text {rd }}$ para starting with "Franz Simon...."

The updated online version of the book can be found at: https://doi.org/10.1007/978-3-030-61199-6_1 https://doi.org/10.1007/978-3-030-61199-6_2 https://doi.org/10.1007/978-3-030-61199-6_3 https://doi.org/10.1007/978-3-030-61199-6_4 https://doi.org/10.1007/978-3-030-61199-6_5 https://doi.org/10.1007/978-3-030-61199-6 
In Page 16, the caption of fig. 3.3 has been altered as "Kurt Mendelssohn and colleagues in Breslau circa 1931-1933. Top Left—Nicholas Kurti, Middle LeftRostislav Kaichev, Bottom Row, $3^{\text {rd }}$ and $4^{\text {th }}$ from left-Barbara Zarniko, Kurt Mendelssohn

(Courtesy J. Mendelssohn)

In the paragraph starting with "In 1919...", the content "named to the Professor Lee Chair" has been replaced with "appointed to be the Dr. Lee's Professor"

In Page 17, the content "Mendelssohn's's" in the paragraph starting with "This is....", has been replaced with "Mendelssohn's"

In Page 18, the word "and" has been added between the word "Road" and "was" in the paragraph starting with "Figure 3.4..."

In Page 20, the content "Simon was also being recruited by Cambridge University. Had Franz Simon chosen Cambridge rather than Oxford, Kurt Mendelssohn would have been the senior cryogenics researcher at the Clarendon and his life at Oxford might have been quite different. As it was, Simon was the senior man and was first in line for University Professorships" has been removed from the paragraph starting with "In the fall of 1933...."

\section{Chapter 4:}

In Page 24, the caption of fig. 4.1 has been modified as "Fig. 4.1 Kurt Mendelssohn in his Oxford Laboratory circa 1933-1935. Note the open cryostat in the center of the Fig.

In Page 25, the word ", and" has been added next to the content " $3.3 \mathrm{~K}$ " in the paragraph starting with "Mendelssohn and Moore..."

In Page 39, the word "personal" has been added next to the content "was on" in the paragraph starting with "Kurt Mendelssohn..."

\section{Chapter 5:}

In Page 46, the paragraph starting with "After the war ended. ..." has been removed.

\section{Epilogue:}

In Page 102, the word "twentieth" has been corrected next to the content "in the" in the paragraph starting with "Here we are in 2020..." 